\title{
IS THERE A FUTURE FOR SPECIAL COLLECTIONS? AND SHOULD THERE BE? A POLEMICAL ESSAY
}

OF THE HOLY TRINITY — collecting, preserving, and making accessible precious books, manuscripts, and other special materials-preservation takes precedence. $^{1}$

Following are three brief prefatory notes that will be helpful in understanding this essay. First, readers should note that the word polemical appears in the essay's title. I ask the reader's indulgence in understanding that I mean this word literally. The essay is a polemic. Intended to be serious, it is not therefore also intended to be "balanced" or "fair." In addition, it is an essay, not a paper; and its informality of style is intended to reflect a difference between these two genres.

Second, for several years, this essay has been in public view on my Web site but was, I assumed, essentially unread in that location. Despite what I assumed to be its invisibility, it has become a locus of public debate about the role and function of rare book libraries. At an ARL meeting held in Lawrence, Kansas, in 1999, Dr. Alice Schreyer, curator of special collections at the University of Chicago Library, and Suzanne E. Thorin, Ruth Lilly University dean of university libraries at Indiana University, made the content of my essay a basis for discussion of matters considered here that both of them also find worth additional thought. If, years after it was first 
written and presented, and although unpublished in any traditional sense, the essay was able to provoke such discussion, then perhaps its broader dissemination may be forgiven.

Third, many of my colleagues will find in this discussion matter that is offensive or disagreeable. Others will simply ask, more or less, what I am complaining about, for they already practice the sorts of changes for which the essay calls. Polemic does tend to paint with a broad brush. I apologize in advance to those who feel that they have been tarred by a brush that inadvertently touched them. It is very far from my intention to slur anyone individually or our field corporately. However, it is my intention to propose that reconsideration of some of the essential assumptions our field operates with is overdue. To those who agree with my suggestions but feel they propose changes that already have been implemented, I can only say: I used to think so too, but no longer.

\section{I.}

When I first conceived of this paper, my point was simple and straightforward. ${ }^{2}$ Collections formed primarily to provide for the security of materials, but not for the convenience of users, cost too much for staff and housing and provide too little return in frequency of use to easily justify themselves in an increasingly tough library economy. Managers of such collections must seek innovative ways of increasing their functionality or expect to see these collections cease to exist.

Written in dry, academic, practically inhuman prose, these two sentences appear, on examination, to be formed from the stuff of better bromides.

2. This paper was originally presented at the 67 th annual meeting of the South Carolina Library Association, held in Charleston in December 1993. I am grateful to the association for providing me the impetus to write this paper and especially to my former student, Suzanne Singleton, for instigating the association's invitation. Greater flattery hath no teacher. A later, considerably shortened version was presented at the Philobiblon Club, in Philadelphia, as the 1996 Edwin Wolf Memorial Lecture; and the paper was presented once again at the University of Virginia's Rare Book School in 1999. Comment on all these occasions has been extremely useful to me as I continue to consider the issues I raise in this essay. 
Not a sentiment they contain would fail to pass muster with the most utterly Philistine of library directors or trustees - or even those librarians (and there are many of them) who think special collections a waste of time. Not a sentiment they contain would surprise or interest them, either.

Their point continues to interest me, but as this essay developed, I changed the terms in which I originally planned to argue it. First, the point does not rest on any appeal to economic hard times. Second, words such as managers and functionality pay obeisance to a business ideology I find neither relevant nor interesting. What most pushed me to change the approach I first planned for this paper, however, was not merely the growing courage of my own convictions — stupid, banal, or otherwise-but, rather, a visit to another special collection.

Standing in the alien, but familiar, precincts of another institutional context, hallowed to some other scholar's and some other librarian's obsessions, I listened to an exceptionally well-presented set speech delivered by a person who loves the materials with which she works and is astonishingly articulate about them and their function. She told her audience about how labor-intensive her readers are, how she must schedule their visits with great care, how much supervision and assistance they require, how physically difficult her materials are to use, and how her security needs have grown. In short, she told us, in specific, all the things I was taught generally, in both library school and my first job as a rare book librarian. I listened to her with admiration-and unexpected, intense, and growing dismay.

What she conveyed so well was not merely knowledge and enthusiasm, although she conveyed both of these abundantly, but also attitudeswhat, in a different context, I called a moment ago an ideology. These, too, she conveyed abundantly. Because they are the standard attitudes of my profession, one rarely thinks about them. When one does, they seem merely self-evident. 
I absorbed such attitudes long ago, or so I had thought. I have experienced some of the best and worst that a career such as this one can offer, have done so over what is beginning to be a noticeable chunk of years, and bear at least a superficial resemblance to someone who has been considered a leading figure in the field. Therefore, something seems to be seriously wrong with me, for despite this experience and a long past spent working in and writing and teaching about special collections, as I listened to this entirely admirable person present her spiel, I hated it. I admired her knowledge of and enthusiasm for her materials. I loathed the way she spoke about bringing those materials together with her readers. Why?

My efforts to answer this simple question require some autobiographical digressions. If you were taught, as I was, that librarianship is a social science, you may distrust an autobiographical approach. But the social sciences have changed since I was in school and, as sociologist Robert $\mathrm{N}$. Bellah reminds us, introducing a profoundly autobiographical work by a young ethnologist, "knowing in the human sciences is always emotional and moral as well as intellectual." So let me turn to the emotional, perhaps even the moral, and what is certainly the personal; and begin.

II.

I do so with a truism, even if not a particularly pleasurable one. Special collections are not the most admired, special collections librarians not the best liked, parts and people within most of our libraries. The field has changed noticeably in many ways since I started out in it, but this unpleasant sense of its difference-although I and others like me have hoped, occasionally even in print, that it was becoming a thing of the past - has not been one of them. This sense of difference, like other aspects of the

3. Robert N. Bellah, "Foreword," in Paul Rabinow, Reflections on Fieldwork in Morocco (Berkeley: Univ. of California Pr., 1977), xi. Such an approach is usually discredited by being labeled "anecdotal individualism" (a term I take from Patricia J. Williams, The Alchemy of Race and Rights [Cambridge, Mass.: Harvard Univ. Pr., 1991], 6; she approves of anecdotal individualism). I plead guilty. 
ideology of rare book librarianship, is something we all begin to absorb very early. In my case, such absorption began long before I ever thought special collections might be a field I would enter.

I spent four years as an undergraduate English major at a picture-postcardpretty little New England college without once seeing a rare book or manuscript. It is not that the place I went to was so impoverished or benighted that it had none: far from it. It had noteworthy collections of the literature of the Irish Renaissance, of Thomas Hardy, and of a variety of New England writers. It also must have had then, for it does now, a copy or two of an older book of English or American literature or history floating around. Yet it never seems to have crossed anyone's mind that these might be things a young person could want to see, to touch, perhaps even-God forbid!- - to read. "Anyone," in this case, was the rare book librarian. He was also a specialist in the American Renaissance and Jewett, and, at least as I (surely unfairly) remember him, he might as well have worn a sign about his neck reading Noli me tangere (or my books, either). His demeanor-to students, at any rate-would have chilled beer.

As a graduate student at New York University, I was too specialized for that institution's collections, which were concentrated in periods later than my own interests. On the other hand, it still crossed no one's mind that students_-graduate students, for goodness' sake!-ought to see such materials somewhere before going off to teach literature, that is, stuff that once upon a time had not been printed in a textbook. Should I blame the teachers? the librarians? And does it matter? By the time I was beavering away at my dissertation, I had developed what was to prove a permanent, not to say regrettable, peculiarity: I was interested in seeing, occasionally even in reading, just such things. Because I specialized in literature of the English Renaissance, the library resources of a distinguished Ivy League university some miles to the north of New York University would have been perfect for me; but I never dreamed that they might be open to me. I was right: they were not. I could, if necessary, use the even richer resources 
of The New York Public Library, which was open to anyone over the age of eighteen who seemed on the right side of clean; and, thanks to an indulgent father, I was eventually able to use The British Library.

Imagine my surprise, however, when some years later, now a student at that same distinguished Ivy League university where I would earn a library degree and later be an occasional member of the faculty, I found the rich resources of its special collections department still, in effect, closed to me. I would need to argue on an ad hoc basis for the privilege of using its materials each time I wanted to. Alas, I tend to be a browser and a burrower. Sometimes-most times-I read out of curiosity and only later discover or decide that what I have read is relevant to some point or other I want to write about, maybe just because I happened to read it. The keepers did not approve of this approach; and without a good excuse, one got no reader's ticket. I was then, and remain, a bit too stuffy to have lied my way in. Apart from one use of the department in 1975 for a mandated exercise for students, I have read there only once, in 1993. (It was a legitimate use of the collection, even by their loopy standards, I am happy to report.) And, oh, yes, I once, this time as a faculty member, took a class I was teaching at good ol' distinguished Ivy U for a formal visit, not an experience I chose ever again to repeat.

Oh, well, such are the vagaries at the peculiar places to which that guy went to school, you may be saying; so let me leave my own biography for a moment and refer to my wife's. She went to the same college as I; no differences there. For graduate school, however, she attended an Extremely Ivy League University. While there, she discovered whole libraries she could not use without special permission. A fully registered graduate student, documents quite in order, she would, one day, be ejected into the universe by this very institution with what seem perfectly respectable M.Phil. and Ph.D. degrees; and just as they promised she would, when she grew up she became a published scholar, one who has even been translated into Japanese, a full professor, and a department chairperson. Nonetheless, while she was a student at that Extremely Ivy League University, she was deemed to suffer 
from an irremediable genetic deficiency (viz.: no Y-chromosome, which in those days made A Big Difference at that distinguished place). This deficiency prevented her, along with an entire class of similarly challenged students, from using certain of the institution's special collections resources. One might have thought - and, well, one would have thought wrong.

These are, in fact, stories that could be multiplied with great ease. All of us know people who have been turned away from, had difficulties at, or experienced condescension, downright rudeness, or suspicion of their integrity, cleanliness, or general demeanor while trying to use-or simply not been encouraged to think about using-rare book and manuscript repositories. In fact, as I was writing an early draft of this paper, a person using some of our reference materials told me another such story, dating from a visit just two weeks previously to a famous American research library: its victim was himself, a reasonably well-known antiquarian bookseller. No wonder my colleagues-and, I suppose, I-have such marvelous reputations in the world. We exist, viewed from one not entirely unreasonable perspective, not to bring readers and books together but, rather, to keep them as far apart as possible. Always, of course, with the best interests of the books in mind.

III.

"The best interests of the books." Here is the inescapable tension at the heart of special collections librarianship. So we have always been taught, so I have taught in my turn, so my admirable colleague told her audience when we visited her special collection. On the one hand, readers need access; on the other, our materials need protection. Variably commensurable values contend in uneasy relation with each other: openness and security, use and preservation, people and objects. We can ignore neither side of these pairs, yet both have the constant potential to conflict. In special collections, after all, the materials for which we care may be-often are-uncommon, sometimes unique, often old, frequently fragile, or just plain expensive and irreplaceable. 
Our responsibility is not just to the reader who walks in off the street today but also to that reader's children and great-great-grandchildren, as well as to the fiduciary interests in our holdings of the institutions that employ us, to keep and preserve those materials for future use unto the nth generation.

And there is the root of the sense of difference between general and special collections, the one distinguishing fact that makes special collections "special." The rest of our libraries circulate their stuff promiscuously to just any old one. People, being people, take it home, drop spaghetti sauce on it, leave it on a windowsill during the rain, sneeze on it when they have colds, write in the margins, and - good grief! — may do all these things and be nobody important at all. In institutions such as mine, they may prove to be that low and loathsome form of life, the undergraduate. In the bad old days, at places such as Extremely Ivy League University, they might be female. At a public library, they might turn out to lack any academic credentials whatsoever, might even prove to be downright boobies.

Our stuff simply cannot be subjected to such risks. Too valuable, too rare, too precious, it is the stuff of scholarship. It exists to be the happy hunting ground of scholars. It should be kept for them, their students, and their work.

I agree that this is not an utterly insane point of view. But, contrary to accepted mythologies, it is by no means the only point of view that is conceivable.

I have used (as a reader) and worked (as an employee) in libraries here and abroad. I have read a bit in library history. And I have come increasingly to feel that American special collections are not only a troublesome concept in theory, but also-generally speaking-worse in practice. Our theory too easily justifies a broad range of practices that, however well intentioned they may be, prove in execution - even when they are not simply idiotic, as, too frequently, they are-to be mean-spirited, judgmental, exclusionary, hierarchical, and otiose. 
If I am even close to being right, which I say with what I hope is a due regard for the possibility that I have instead declined into the rhetorical overkill that polemic occasionally elicits, these ought to be very strong reasons encouraging us to reexamine that theory from the ground up. Let me start with an obvious question. What are we protecting so zealously? When all the lip service to scholarship and uniqueness and fragility has been rendered, after all that lip service to noble ideals, the only answer, I think, that makes any sense at all is: What we are protecting is money. (Fragility, by the way? Who has ever turned the leaves of the average incunable with that criterion in mind and not realized instantly that they're going to outlast all of us and will do so quite handily right down to that mythical nth generation for which we wait with bated breath, even if we do-maybe especially if we do-nothing to them at all?) The stuff costs a lot to buy, more to replace, if it even can be replaced, and we will get fired if we lose it. Money-and ourselves.

Money is not a bad answer when you come right down to it. But if money is not the answer, what are we doing in the rest of our libraries? Consider the relative prices of eighteenth-century novels and, let us say, many workaday medical reference books or, perhaps, Chemical Abstracts. When I recently acquired for my current library an unrecorded eighteenth-century American imprint, it cost my institutional exchequer twenty-five dollars. Perhaps, however, a comparison between "rare books" and medical and scientific reference books and journals loads the dice. Consider, instead, what circulates every day in our fine arts collections. This field is a minor interest of mine, so I occasionally look at dealers' catalogs in it, not catalogs published by "antiquarian" booksellers, just those issued by "used" booksellers. Books my library owns, books I own and for which I can well recall paying what I thought then was the outrageous price of seventeen dollars, now sell routinely in the low to mid three figures-if you can find them at all. What is the difference here? There must be one, must be some principled development of thought and logic that underlies the ways we library 
scientists ordinarily differentiate between pricey old books and pricey recent ones_but I fear I am missing it.

I think, to be fair, that it must reside in our more or less visceral suspicion that a recent book will turn up, if need be, whereas the older one will not: hence our decline into overprotectiveness. Yet, my own experience fails to support such comparative optimism about the easy attainability of the recent, on the one hand, and pessimism about the difficult attainability of the not so recent, on the other.

Several years ago, my institution arranged a trade with a special collection at another university's library. An alumnus had given that institution an immense collection of books, mostly from the English eighteenth century, united by nothing more or less than their provenance. The donor had recreated the library of an eighteenth-century English nobleman and writer. No slouch, this donor had not bought merely the titles he knew to have been in his beau ideal's library; he had sought for, and with surprising frequency had found, the very copies that had once lived there.

But, of course, he had not found all of them. Some had disappeared. Others, rebound, had lost indications of their provenance. Yet others were owned by other collectors. Some, in fact, had wound up at Penn, including one issue of Thomas Hobbes's bibliographically complex Leviathan and a copy of David Dalrymple's Memorials and Letters Relating to the History of Britain in the Reign of James the First. These volumes no longer bore the bookplate of their eighteenth-century owner. But each bore identifying shelf marks from his library, known from the published bibliography, as accessible to us as to anyone else. The two books I have mentioned (there were a few others, as well), because they exist in different issues and editions, posed problems.

The donor had known that his man had owned Hobbes and Dalrymple, but he had not known what issue or edition of either had been in his library. The donor had guessed wrong in both cases, buying copies that his 
man might have owned but which, when our copies turned up, proved not to have been the right ones. Leviathan ought to have been represented by one of the odd issues; reasonably enough, however, the donor had acquired one of the more ordinary ones. We simply gave our copy to these folks on long-term deposit, after they assured us that whenever a copy turned up of the specific issue we had given them, they would buy it for us. Completion of this transaction required less than three years. The cost of the replacement was under fifteen hundred dollars.

Dalrymple posed a different question. Our copy was the second edition of 1766; their donor, again, reasonably enough, had acquired a copy of the first edition of 1762 . They gave that first edition to us, and we gave them our copy of the second, which bore the provenance they needed. I remained uneasy. Having never read Dalrymple, I did not know if there might be some significant variation, substantive or not, between the 1762 first and 1766 second editions. Moreover, Penn had once owned the 1766 edition, its presence had been reported to various bibliographical databases, and one could foresee a day when its absence might pose someone a bad hour or two. So I kept an eye out for a copy of the second edition, hoping against hope that this 1766 work might turn up at a price I would not mind paying. It did, as it happens, and even more rapidly than Hobbes. The search (an informal one, by the way, which simply meant that I read dealers' catalogs with this want in mind) took less than sixteen months, and the cost of the replacement copy was something under one hundred and fifty dollars (this for a book printed in Glasgow by the Foulis Press, which is considered collectible in its own right).

The older books we call irreplaceable and expensive may well prove to be just that. However, my strong impression is that they are irreplaceable and expensive far less frequently than we like to scare ourselves into believing, so as - dare I to speculate? - to justify a set of restrictive practices and selfaggrandizing differentiations that make special collections "special." Let me point out the obvious contrast quickly. In 1970, I began to search for a novel 
written by an American woman entitled The Narrow Lyre. It is, I think, a good book, and I wanted to add it to libraries where I work, not for special but, rather, general collections. It is a book that deserves to circulate and be read. I even wanted a copy for myself. Until 1998, I had never seen a copy other than the one I had borrowed to read through interlibrary loan (ILL) many years ago. (The copy that eventually reached me came from the Library of Congress.) This book was not published in Walpole, Massachusetts, in 1797, nor in Charleston in 1818. Rather, it was published in New York City in 1956 by Harper; its author is Janice Warnke. I sought this book, published in the normal way since World War II by a major American trade publisher, not for sixteen months nor for three years but, rather, for more than twenty-five years. When I found it, or rather them, (deo gratias! two copies, one for my library and one for me), they were the only other two copies of this book I have seen. As of the spring of 2000, I have now heard of a third.

What distinguishes the majority of the books in special collections from books in general circulation is not quite so much their expense or irreplaceability as we like to think, in short. If these criteria really are determinant, the open circulation policies that define most American libraries are in grave error and we should all —not just special collections departments, but the whole shooting match - emulate the models of The New York Public or British Libraries, or the Bodleian Library at Oxford, turning ourselves into repositories where books may be read on-site but never leave the premises.

That is not going to happen, of course. At my own university, which I take to be typical in this respect, any effort to turn the main library into a noncirculating collection would require, first and foremost, vast alterations to the physical fabric of the building. No responsible institutional administrator would permit any such thing; none could begin to afford it. Our library was built on the assumption of open-stack access to, and ease of circulation from, the collections. We cannot close off access to our stacks to keep books from circulating illicitly (they already do so, of course), and also 
build and staff reading rooms with sufficient seating to permit easy on-site use of our collections, unless we build an entirely new and different library building from the ground up.

That is just the physical problem. Much more incendiary would be the response of our students and faculty, all of whom take it as their God-given right to circulate the majority of our collections, take the books home, sneeze on them if they happen to be reading them while they have a cold, drop spaghetti sauce on them, and do all the other horrible things people do to books all the time. And, by the bye, which they have done to books at all times since there were books, even going so far as to write on them. (I cannot be the only person in our field who thinks that the emphasis on pristine condition in collecting modern first editions is misplaced, indicative merely of the fact that the book has never been [yuck!] read. One of the things that excites me about older books is precisely marks, comments, marginalia, showing that they have had early readers and occasionally even indicative of those readers' responses.)

The books in special collections are normally in better shape than the books that circulate; they are better made, they are used less frequently, and they get slightly better care. They can be located in the trade pretty easily because they usually are known to have a market. No one in the field of modern firsts has ever heard the name of Janice Warnke; I, and a now-dead friend who reviewed her second (easy-to-find) book for The New York Times, are the only people I know who have ever read a line she wrote. She is not worth sticking in a catalog. I thought I would find a copy, if I were lucky, at an AAUW or Bryn Mawr book sale and, instead, found two over the Internet; but she is not going to be "rediscovered" in my lifetime (or hers; so far as I know, she is still alive). On the other hand, even the least amusing eighteenth-century novelist or most derivative sixteenth-century writer of neolatin poetry is worth cataloging, if for no other reason than his or her sheer age. If I look long and hard enough, and reach the telephone quickly enough, I can replace almost any such work for which replacement may prove necessary. 


\section{IV.}

I think our priorities may be misplaced. But because of how they are misplaced, I have the right - in fact, am thought to have the responsibility-to quiz readers who show up in my reading room. Before allowing them to use our materials, I ought to get their name, rank, and serial number; look at their hands for dirt; keep them under constant surveillance while they use the materials for which I care; and ask them whether they know enough to use the book for which they knew enough to ask.

Am I making this up? Before being permitted to use a sixteenth-century manuscript at another institution than my own, a scholar I know well was made to demonstrate her ability to read it by reading from it aloud to the keeper at that institution (it was written in a particularly difficult English secretary hand). Who, if I may be so bold, the hell was he? I know who the reader is, and I also know what her "qualifications" to use the manuscript in question are, as well. She is my wife; the library is at CambridgeEngland, not Massachusetts - and, in case it matters, she had gone to Cambridge to see this one manuscript only after working her way through some forty and more of the same writer's manuscripts at Oxford's Bodleian Library. She knew much more about the writer of the manuscript and his handwriting than the person quizzing her.

But as soon as I tell this tale, I am also saying something about where I think our models - attitudinal, ideological, behavioral-all too frequently come from. Translate this situation into American terms, if you can, without, for the moment, thinking "special collections." It is not easy-it is very nearly impossible-to do. For instance, what exactly does the word qualifications mean? Who is "qualified," by what standards and by whose, to read Plato's Republic, Hobbes's Leviathan, Marx, Hitler, Kaye Gibbons, or Ernest Gaines? We never ask such questions at a circulation desk. Maybe we should. But we do not. Because we do not in that place, what in the world gives the Cambridge keeper-or me- 
the right to ask these questions of readers who wander into special collections?

Should I quiz the student who asks to see Shakespeare's First Folio? I am supposed to, but on what basis? And even if there were an obvious reason to ask the question, what, then, would a good answer be? Is it, for instance, appropriate for a student taking a course on Shakespeare to ask to see the First Folio to read a play in it? If the student has the play's text in her textbook, why should I suppose her to be ignorant of this rather elementary piece of information and think she just did not look, or failed to flip through enough catalog cards or online records to find a circulating copy?

If there is a particular genius to American librarianship, and I think there is, it is in our history of abandonment of older European and English models. These determined who did and did not get access to libraries by starting with the more or less automatic assumption that few, rather than many, merited such access. Our history is, rather, one of growing accommodation to ideals of unquestioned access, openness, and the right of the reader to read any damned thing, no matter how vile or disgusting, he or she pleases-and no matter who (or how vile and disgusting) he or she seems.

We have learned these lessons with difficulty. In many respects we are still learning them. We have increased our hours of opening, just for starters, since Dartmouth College (to give only one example) opened its library "to the two upper classes on Monday and to others on Tuesday, of each week from one o'clock to two." And we have broadened the stock of materials we think appropriate for our libraries to contain and to circulate. Times have changed since, at Harvard, Cotton Mather asked whether students were reading "plays, novels, [and] empty and vicious pieces of poetry." Nowadays, no one asks; and the empty and vicious come off our shelves in a wider 
variety of flavors than Mather would have dared imagine. True, we do not do as well as we might in including in our collections the works of the politically, religiously, racially, geographically, sexually, or gendered undesirables who form so surprisingly large a component of American society. None the less, we try to do well in this respect.

Except in special collections, where we have standards. There, our models are the sorts of libraries that kept Virginia Woolf from using them because she was a woman, or those that imposed tests of one sort or another before allowing applicants to become readers. No one in my field lacks stories of this sort, told, often enough, as if they were funny. They are the stories from which we learn the ideology of our trade, which socialize us into this field.

One example of the genre, a story I think I owe to Terry Belanger, may be apocryphal, but that does not really matter from the point of view of the story's function. It is a story about the famous art historian Millard Meiss, long before he had become "the famous art historian Millard Meiss." Just after he had completed his doctorate and was returning to the United States from graduate school in Germany, he stopped off in Paris at the Bibliothèque nationale to see a particular illuminated manuscript. It would be in part for his studies of illuminated manuscripts that Meiss ultimately became "the famous art historian Millard Meiss." But when he called for it, he was refused. This manuscript, it was explained to him, is too precious to be used; therefore, no one sees it. What, the silly, brash, and youthful American asked, are you keeping it for? Posterity, was the reply. Tell the Keeper that Posterity has just arrived, the undeterred Meiss is said to have responded; and mirabile dictu, whether because he or she thought Americans were posterity or simply because he or she had grown tired of arguing, the French keeper agreed. Both the manuscript and Meiss were placed together in the reading room.

There, while examining it, Meiss felt a tap on his shoulder. "Excuse me," came a timorous query from a graybeard behind him, "but are you, by any chance, looking at manuscript number so and so?" "Why, yes," said Meiss. 
"Would you be very discommoded," the man went on, "were I to look at it with you, over your shoulder?" "Not at all," said Meiss. They examined it together. When they had done, the older man covered the fresh, newly-bePh.D.-ed Meiss with thanks, telling him what an honor it was to be able at long last to have seen that manuscript for which he had been asking for many years, and also to have seen it in such distinguished company. "But what," said Meiss, still after all this a naïf, "can possibly have prevented you from doing so?" "Alas," responded the stranger, "they never show this manuscript to just anyone. You," he continued, "must be very distinguished; I am embarrassed to say that I do not recognize you." "Who, me?" replied Meiss. "I am Millard Meiss, and who are you?" "I, alas," came the reply, "am a mere nobody, just the professor of art history here at the Sorbonne."

A story such as this has a double edge: It warns the budding curators to whom it is told that they need to be careful about whom they keep out; but, simultaneously, it asserts their right to question those who want in. "Posterity!" we cry, and thus (although, in the instance the story retails, "we" may have begun by making a teensy-weensy little mistake), we remind ourselves that we work at the sorts of places whose curators and keepers and staffs are bastions of the old standards, preservers-literal preservers-of Culture.

Is this what rare book librarianship was supposed to be about? I am far from sure that it is. In fact, I am dangerously close to certain that it is not. And I am even more perilously close to fearing that I have not exactly caricatured what I would criticize, either.

\section{V.}

We need to be more like, not more unlike, other American libraries if we are to justify our survival. No more than our colleagues elsewhere have we got the patent, the final word, on what is culture, who can or should have 
access to it, and what its preservation requires. The stuff is organic; like us, it is going to die sooner or later or, unlike us, require some sort of reformatting if its text must be preserved for subsequent generations. While it is alive, why should it not get used, felt, touched, admired, smelled, by real live people with real live interests and varied competencies of which we might not approve, but which we also have no right or ability to judge?

Am I saying, raise the floodgates and let the barbarians (or whatever they are) in? I know that no such thing is going to happen. ${ }^{6}$ I may think that it should happen, but I can easily guess the number of people, particularly institutional administrators, who would agree with me; and there seems little reason to propose policies that have no chance at a live birth. In fact, however, I am arguing for something a bit more difficult.

We do not ask enough questions of ourselves about our attitudes or our purposes in our specific situations. Instead of allowing unquestioned assumptions, ideology that unconsciously asserts its own general applicability, to determine our behavior, we should ask such questions. Moreover, as a corollary, we should assume that fewer blanket responses will adequately cover the questions we ask, trying instead to imagine answers that help us to distinguish between the functions and needs of one place and another, one format and another. What may be appropriate behavior at Cambridge or Paris may not be appropriate at a university in Philadelphia, Charlottesville, or Lawrence, Kansas. What may be appropriate behavior with printed books may or may not be equally appropriate with older bound codex manuscripts, modern manuscripts, or archives; perhaps distinctions need to be made even among materials that we normally classify in similar ways. What may be appropriate behavior at a repository without a resident student and faculty population and with de facto

\footnotetext{
6. Sidney F. Huttner wrote, "... I realized how incredibly successful we have been, collectively, in locking things up. What would happen if we dropped the locks? Would anyone care?" ("Waving Not Drowning: Rare Books and Manuscripts in a Digital Age," Rare Books and Mamuscripts Librarianship 13, no. 2 [1998]:103).
} 
national repository functions (the Library of Congress, The New York Public Library, the American Antiquarian Society) may not be appropriate for the University of Arizona, the Cleveland Public Library, or Harvard. What may be appropriate behavior for the New England Historic Genealogical Society or the Mormon genealogical repository in Utah may be inappropriate at the local history and genealogy collections at Easton, Pennsylvania, or Darlington, South Carolina. Put a bit more positively, what has worked elsewhere in American librarianship-even for other parts of the libraries at Penn, Kansas, or Cleveland-may work in some, even if not all, American special collections, as well.

What might this kind of change in attitude mean in practice? The aggressive pursuit and encouragement of instructors and of their classes to visit special collections, not a passive wait for their requests for such visits, might be an easy place to start changing the role of special collections within an academic community. Library staff can initiate conversations across as much of a university's spectrum as can be reached and urge instructors to bring their classes, graduate and undergraduate, to see materials in their original form and to learn why anyone might want to use them in their original form, wherever such a visit might be relevant-or just plain fun.

Relatedly, library staff can initiate some ongoing noncredit seminars that draw on the resources peculiar to special collections departments and that will bring library staff into close touch with instructional staff and students. Book history and bibliographical and textual issues, an obvious area for such seminars, interest more than English and American literature students. The practitioners of any text-based discipline-classics, philosophy, musicmust be concerned with the material means by which the basic texts of that discipline were transmitted in written and printed form across time. This is a concern, in fact, that current trends in academic theory have increased dramatically. The collaboration of students, faculty, and special collections staff on such seminars will itself prove an important means of integrating 
library staff into the academic life of an institution. Such seminars and their organization will be time-consuming. But they will also give an institution's materials an airing before potential readers who may not have known that this sort of stuff was present for them to work with in their own institutions, or even that these kinds of questions might be asked. Texts, after all, do not fall from the printer as did the Ten Commandments upon Moses, divinely inscribed upon stone. We know this. It can be something of a surprise to learn how many students and their teachers do not know it.

How cumbersome do registration procedures need to be? In some institutions, students who are fully registered have to re-register to use their own library's special collections department, even if they can present an up-to-date, current institutional ID card with photograph. In an era when registration records are electronically accessible, what useful function does a reading room registration process serve, other than to make slightly more off-putting than it needs to be an experience that is already quite awesome enough for most users?

Are there good reasons not to allow some members of the faculty to browse collections? Unsupervised; giving them the key? In the rankings of special collections sins, this one would dump anyone who practiced it immediately into the eighth, if not ninth, circle of Hell. Why? University libraries are formed for use, not show. Are special collections somehow exempt from this function? Some faculty use libraries the same way I use libraries: as I have already mentioned, I browse. Of course, I can browse in our special collections; I work here, they do not. But wait a minute, they do work here, too; they just work for a different part of the institution-the part, if I remember correctly, we tell ourselves we and our library exist to support. One need not tell them they can take the books home, just that they can browse among them and see what they might otherwise not see, being less expert users even of our most user-friendly online catalogs than we are. I, who know how to use both our card and online catalogs better than they do, still more frequently browse our stacks myself - and I know why the ability to do so is so significant. What you find whenever you browse in 
stacks is the book you did not already know about and hence could not have looked up.

If there is some doubt about whether the sin of allowing faculty to browse rates the eighth or the ninth circle of Hell, there would be no doubt were I to suggest the same thing with students: ninth circle it is, the sooner the better. I am sure this is A Bad Thing-and am waiting for someone who can tell me, in words of one syllable, why.

I learned to love books as a browser in library stacks; and most stacks in which I browsed could have been - and were-ripped off regularly. They were ripped off by a very small number of people whose misdeeds (it is at least arguable) ought not to condemn their more honest peers to conditions that make their ability to pursue their work awkward. If American libraries ever return to restrictive procedures with respect to materials in general circulation, any relaxation of procedures instituted for special collections would also require reconsideration. But until then, in some libraries, in some situations, and with a proper attention to what some institutions conceive their function to be, even if for no one else, student browsing privileges might be worth a thought. I know what the costs of theft can be; I feel these costs daily and pay for some of them, too. Even so, I am utterly unwilling to grant final victory to the thieves by curtailing our users' ability to make the fullest possible legitimate use of our collections out of fear that some tiny percentage of them will also prove to be thieves.

\section{VI.}

These suggestions are not an answer for everyone. They are not the entire answer, nor a finished answer, for anyone, either. I do think they suggest a few of the many areas in which we must continue to think about what it is we want the special collections we have created to be when they grow up. For growing up they are-and perhaps already have done-and yet, by and 
large, they remain shackled to the conceptions we had of them when they were new, youthful, largely untried, and unknown.

Research, reading, knowledge, preservation of "the national (or cultural) record," general self-improvement, or just plain pleasure-whatever we conceive our varied institutional missions to be, the rigid separation into two entirely different modes of operating general and special collections simply does no one any good.

I find myself heading to Charleston to give a talk — the genesis of this essay, as it happens. I have been to South Carolina only once before in my life, to visit the art collection at Bob Jones University in Greenville in 1973. This time, I think, I want to find out something about South Carolina. So I poddle around in my library, read James Merrell's 1989 book about the Catawbas, and think, "Hmmm, that's interesting." Then I wander over to William Gilmore Simms's 1835 novel The Yemassee, which deals with related issues. I read it, look up some later editions of Simms, discover F.O.C. Darley's illustrations for the 1853 edition, and think, "Gee, they're very curious, I wonder why he chose those scenes to illustrate," and pretty soon, I have become curious about a book with a question that will take me to a slew of materials in general, special, and fine arts collections. I do not care where they are located when I am behaving as a reader. All I care about is being able to use these materials as expeditiously as possible. My experience in American libraries has taught me that this is a reasonable expectation. I do not have to show up at the door some days in advance of the work I expect to do, having budgeted enough time to permit me to be searched to find out whether I am an IRA terrorist bent on demolishing Panizzi's main reading room, get photographed for a special library user's ID, and then hand in call slips and wait two days to be told that my books were destroyed by enemy action. I think this is a pretty good thing about American libraries. It ought to be a pretty good thing in them as much as possible across the board, even in special collections. If not for readers, than for whom are we saving all this stuff? 
America's special collections have a future, at least insofar as our colleges, universities, public libraries, and reading and writing have a future. The world in which these institutions and activities exist and persist, however, is changing radically, not in the direction of increased restrictions but toward expanded access and openness. Every study of the impact of the Internet suggests that, even despite efforts to privatize intellectual capital, this is one of its most important outcomescertainly in libraries.

Special collections will survive. Too much has been invested in them for them not to survive. But unless we who staff them demonstrate an imaginative willingness to come to grips with this fundamental drive toward increasing openness, I, for one, will anticipate not their thriving future but, rather, their increasing marginalization in the teaching and research processes they claim to support. And, though they have been my career, I will be far from certain that their survival is cause for rejoicing. 